\title{
Antioxidant, cytotoxic and analgesic activities of the methanolic fruit extract of Terminalia chebula Retz.
}

\author{
*Shammy Sarwar', Asif Hasan Malik', Muhammad Ashikur Rahman², Md. Zakiur Rahman³, Md. Sohel Rana² \\ ${ }^{1}$ Department of Pharmacy, Stamford University Bangladesh, 51, Siddeswari Road, Dhaka-1217, Bangladesh \\ 2 Department of Pharmacy, Jahangirnagar University, Savar, Dhaka, Bangladesh \\ ${ }^{3}$ Department of Pharmacy, East West University, Dhaka-1212, Bangladesh
}

\begin{abstract}
The present study was aimed to investigate antioxidant, analgesic and cytotoxic activity of the methanolic extract of Terminalia chebula Retz. fruits. Antioxidant potential of the extract was evaluated by using nitric oxide scavenging assay, reducing power and total antioxidant capacity. The extract showed significant activities in all antioxidant assays compared to ascorbic acid in a dose dependent mode. In nitric oxide scavenging assay, the IC 50 value of the extract was found to be $51.3 \mu \mathrm{g} / \mathrm{mL}$ while the IC 50 value of ascorbic acid was $77.4 \mu \mathrm{g} / \mathrm{mL}$. In addition to strong reducing power, total antioxidant activity of the extract was also found to increase in a dose dependent manner. The analgesic activity was evaluated using acetic acid-induced writhing test in mice. The extract, at a dose of $500 \mathrm{mg} / \mathrm{kg}$, showed a maximum of $44.17 \%$ inhibition $(p<0.05)$ of writhing reaction compared to the reference drug diclofenac-sodium $(66.96 \%)$. The extract also showed moderate cytotoxic activity in brine shrimp lethality bioassay and the LC50 value was found to be $97.36 \mu \mathrm{g} / \mathrm{mL}$.
\end{abstract}

Key Words: Terminalia chebula Retz., antioxidant, analgesic, cytotoxicity.

\section{INTRODUCTION}

Terminalia Chebula has been extensively used in ayurveda, unani \& homoeopathic medicine and has become cynosure of modern medicine. The Sanskrit name 'Haritaki' is rich with meaning, referring to the yellowish dye (harita) that contains the god Siva (Hari, i.e. the Himalayas and that it cures (harayet) all the diseases (Das, 1991). Its other commonly used Sanskrit name, Abhaya, refers to the 'fearlessness' it provides in the face of the disease. According to Indian mythology, this plant originated from the drops of ambrosia (Amrita) which fell on the earth when Indra was drinking it (Srikanthmurthy et al., 2000). T. Chebula possesses a wide variety of activities like antimicrobial (Sato et al., 1997), antioxidant (Cheng et al., 2003), antiviral (Jeong et al., 2002), anticarcinogenic (Hushum et al., 2002), hypocholesterolemic (Thakur et al., 1988), radioprotective (Gandhi et al., 2005), antispasmodic \& antipurgative (Miglani et al., 1971).

Literature reviews pointed out that no studies combining the antioxidant, analgesic and cytotoxic activities of the fruit have so far been undertaken. Coupled with our continuous interest of pharmacological screening of Bangladeshi medicinal plants, in this study we aimed to investigate antioxidant, analgesic and cytotoxic activities of the methalonic extract of $T$. chebula.

\section{MATERIALS AND METHODS}

\section{Chemicals and drugs}

Ascorbic acid was obtained from SD Fine Chem. Ltd., Biosar, India. Ferricchloride was obtained from Sigma Chemical Co and Potassium ferricyanide was from May and Backer, Dagenham, UK. Methanol, DMSO (dimethyl sulfoxide) and Ammonium molybdate was purchased

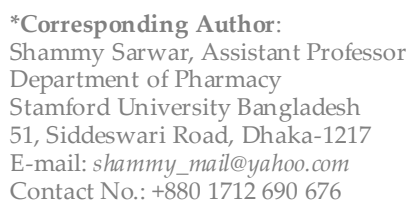

from Merck, Germany. Diclofenac-Na was collected from Square Pharmaceuticals Ltd., Bangladesh.

\section{Plant material}

The plant Terminalia chebula Retz. was collected from Dhaka in the month of May 2013. A voucher specimen for this collection has been maintained in Bangladesh National Herbarium, Dhaka, Bangladesh.

\section{Extraction}

The powdered plant sample $(500 \mathrm{~g}$ ) was soaked in $1.5 \mathrm{~L}$ of methanol for 16 days and then filtered through a cotton plug followed by Whattman filter paper number 1 . The extract was concentrated with a rotary evaporator and it afforded $15 \mathrm{~g}$ of the methanol extract.

\section{Animal}

For the experiment Swiss albino mice of either sex, 3-4 weeks of age, weighing between 20-25gm, were collected from the animal research branch of the International Center for Diarrheal Disease and Research, Bangladesh (ICDDR, B). Animals were maintained under standard environmental conditions (temperature: $\left(24.0 \pm 1.0^{\circ} \mathrm{C}\right.$ ) relative humidity: 55-65 \% and 12 hrs light / 12 hrs dark cycle) and had free access to feed and water ad libitum. The animals were acclimatized to laboratory condition for one week prior to experimentation (Chatterjee, 1993). All protocols for animal experiment were approved by the institutional animal research ethical committee.

\section{Phytochemical screening}

The freshly prepared crude extract was qualitatively tested for the presence of various phytochemical constituents. Phytochemical screening of the extract was performed using the following reagents and chemicals: alkaloids with Dragendorff's reagent, flavonoids with the use of $\mathrm{Mg}$ and $\mathrm{HCl}$; tannins with ferric chloride and potassium dichromate solutions and saponins with ability to produce stable foam and steroids with LibermannBurchard reagent. Gum was tested using Molisch reagent 
and concentrated sulfuric acid; reducing sugars with Benedict's reagent. These were identified by characteristic color changes following standard procedures described by Ghani (2005).

\section{Antioxidant Assays \\ Assay of nitric oxide scavenging activity}

The procedure was based on the method, where sodium nitroprusside in aqueous solution at physiological $\mathrm{pH}$ spontaneously generates nitric oxide, which interacts with oxygen to produce nitrite ions that can be estimated using Greiss reagent. Scavengers of nitric oxide compete with oxygen leading to reduced production of nitrite ions. For the experiment, sodium nitroprusside $(10 \mathrm{mM})$ in phosphate buffered saline (PBS) was mixed with different concentrations of methanolic extract of $T$. chebula dissolved in methanol and incubated at room temperature for 150 minutes. The same reaction mixture without the methanol extract but the equivalent amount of methanol served as the control. After the incubation period, $0.5 \mathrm{ml}$ of Greiss reagent [ $1 \%$ sulfanilamide, $2 \% \mathrm{H}_{3} \mathrm{PO}_{4}$ and $0.1 \%$ $\mathrm{N}$-(1-naphthyl) ethylenediamine dihydrochloride] was added. The absorbance of the chromophore formed was read at $546 \mathrm{~nm}$ (Sreejayan and Rao, 1997) using a Hach, DR-4000U spectrophotometer.

\section{Determination of total antioxidant capacity}

The antioxidant activity of the extracts was evaluated by the phosphomolybdenum method according to the procedure of Prieto et al. (1999). The assay is based on the reduction of Mo (VI)-Mo (V) by the extract and subsequent formation of a green phosphate/ $\mathrm{Mo}(\mathrm{V})$ complex at acid $\mathrm{pH}$. $0.3 \mathrm{ml}$ extract was combined with $3 \mathrm{ml}$ of reagent solution $(0.6 \mathrm{M}$ sulfuric acid, $28 \mathrm{mM}$ sodium phosphate and $4 \mathrm{mM}$ ammonium molybdate). The tubes containing the reaction solution were incubated at $95^{\circ} \mathrm{C}$ for 90 minutes. Then the absorbance of the solution was measured at $695 \mathrm{~nm}$ using a spectrophotometer (Hach, DR-4000U) against blank after cooling to room temperature. Methanol $(0.3 \mathrm{ml})$ in the place of extract is used as the blank. The antioxidant activity is expressed as the number of equivalents of ascorbic acid.

\section{Reducing power}

The reducing power of Terminalia chebula was determined according to the method previously described by Oyaizu, 1986. Different concentrations of Terminalia chebula extract $(25-500 \mu \mathrm{g})$ in $1 \mathrm{ml}$ of distilled water were mixed with phosphate buffer $(2.5 \mathrm{ml}, 0.2 \mathrm{M}, \mathrm{pH} 6.6)$ and potassium ferricyanide $\left[\mathrm{K}_{3} \mathrm{Fe}(\mathrm{CN})_{6}\right](2.5 \mathrm{ml}, 1 \%)$. The mixture was incubated at $50^{\circ} \mathrm{C}$ for $20 \mathrm{~min}$. A portion $(2.5 \mathrm{ml})$ of trichloroacetic acid (10\%) was added to the mixture, which was then centrifuged at $3000 \mathrm{rpm}$ for $10 \mathrm{~min}$. The upper layer of the solution $(2.5 \mathrm{ml})$ was mixed with distilled water $(2.5 \mathrm{ml})$ and $\mathrm{FeCl}_{3}(0.5 \mathrm{ml}, 0.1 \%)$ and the absorbance was measured at $700 \mathrm{~nm}$. Increased absorbance of the reaction mixture indicated increased reducing power. Ascorbic acid was used as the reference antioxidant.

\section{Brine Shrimp Lethality Bioassay}

Brine shrimp lethality bioassay was used for probable cytotoxic action (McLaughlin, 1998; Meyer et al., 1982; Persoone, 1980). The eggs of Brine Shrimp (Artemia salina Leach) was collected from local pet shops and hatched in a tank at a tem perature around $37^{\circ} \mathrm{C}$ with constant oxygen supply. Two days were allowed to hatch and mature the nauplii. Stock solution the sample was prepared by dissolving required amount of extract in specific volume of pure dimethyl sulfoxide (DMSO). With the help of a pasteur pipette living nauplii were exposed to different concentrations of the extracts.

Preparation of test groups

$20 \mathrm{mg}$ of sample was dissolved in $2 \mathrm{ml}$ of DMSO to obtain a solution having concentration of $10 \mu \mathrm{g} / \mathrm{ml}$. From that test solution different volumes were added to premarked glass vials or test tubes containing $5 \mathrm{ml}$ of seawater and 10 shrimp nauplii, so as to make the final concentration of samples in the vials or test tubes $200 \mu \mathrm{g} / \mathrm{ml}, 100 \mu \mathrm{g} / \mathrm{ml}, 90$ $\mu \mathrm{g} / \mathrm{ml}, 80 \mu \mathrm{g} / \mathrm{ml}, 70 \mu \mathrm{g} / \mathrm{ml}, 60 \mu \mathrm{g} / \mathrm{ml}, 50 \mu \mathrm{g} / \mathrm{ml}, 40 \mu \mathrm{g} / \mathrm{ml}$, $30 \mu \mathrm{g} / \mathrm{ml}, 20 \mu \mathrm{g} / \mathrm{ml}$ and $10 \mu \mathrm{g} / \mathrm{ml}$.

\section{Counting of nauplii}

After 24 hours, the vials were inspected using a magnifying glass and the number of survived nauplii in each vial was counted. From this data, the percent (\%) of lethality of the brine shrimp nauplii was calculated for each concentration. The median lethal concentration ( $\left.\mathrm{LC}_{50}\right)$ of the test samples was obtained by a plot of percentage of the shrimps killed against the logarithm of the sample concentration.

\section{Analgesic Screening}

Acetic Acid-Induced Writhing Test

The analgesic activity of the samples was also studied using acetic acid-induced writhing model in mice. Test samples and vehicle were administered orally $30 \mathrm{~min}$ before intraperitoneal administration of $0.7 \%$ acetic acid but Diclofenac-Na was administered intraperitonially 15 min before injection of acetic acid. After an interval of 5 min, the mice were observed for specific contraction of body referred to as 'writhing' for the next $10 \mathrm{~min}$ (Ahmed et al., 2004).

\section{Statistical Analysis}

Statistical analysis for animal experiment was carried out using one-way ANOVA followed by Dunnet's multiple comparisons. The results obtained were compared with the vehicle control group. $p$ values $<0.05$ were considered to be statistically significant when compared to the control.

\section{RESULTS AND DISCUSSION}

Reactive oxygen species (ROS) such as superoxide anions, hydrogen peroxide and hydroxyl, nitric oxide radicals, play an important role in oxidative stress related to the pathogenesis of various important diseases (Halliwell and Gutteridge 1999; Finkel and Holbrook, 2000). Antioxidants act as a major defense against radical mediated toxicity by protecting the damages caused by free radicals. It is generally assumed that frequent consumption of plant-derived phytochemicals from vegetables, fruit, tea and herbs may contribute to shift the balance toward an adequate antioxidant status. Thus interest in natural antioxidant, especially of plant origin, has greatly increased in recent years (Jayaprakash and Rao, 2000). In this study, antioxidant potential of the methanol extract of the fruits of Terminalia chebula Retz. was evaluated by using nitric oxide scavenging assay, reducing power and total antioxidant capacity.

The result of NO scavenging activity of the Terminalia chebula Retz. extract is shown in figure 1 . Nitric oxide or reactive nitrogen species, formed during their reaction with oxygen or with superoxides, such as $\mathrm{NO}_{2}, \mathrm{~N}_{2} \mathrm{O}_{4}$, $\mathrm{N}_{3} \mathrm{O}_{4}, \mathrm{NO}_{3}$, and $\mathrm{NO}_{2}$ are very reactive. These compounds 
Table 1: Result of chemical group tests of the methanol extract of T. chebula.

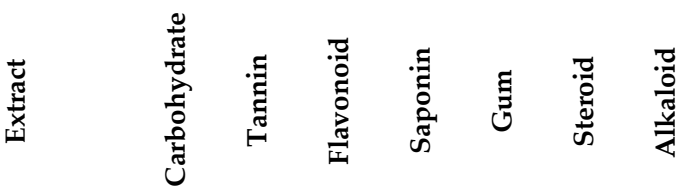

\begin{tabular}{l}
$\begin{array}{l}\text { Methanolic extract } \\
\text { of P.P. emblica }\end{array}$ \\
\hline
\end{tabular}

$(+)=$ Presence; $(-)=$ Absence

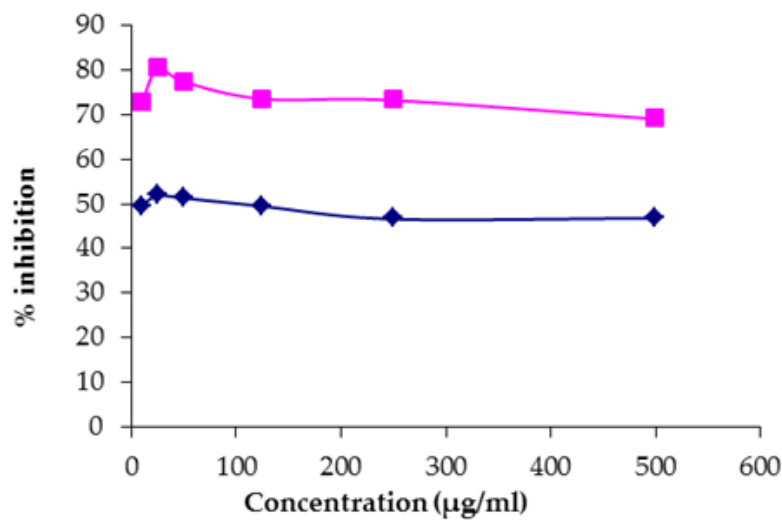

Figure 1: Nitric oxide scavenging activity of Terminalia chebula Retz.vs. ascorbic acid.

are responsible for altering the structural and functional behavior of many cellular components. Incubation of solutions of sodium nitroprusside in phosphate buffer saline at $25^{\circ} \mathrm{C}$ for 2 hours resulted in linear timedependent nitrite production, which is reduced by the extract of $T$. chebula. This may be due to the antioxidant principles in the extract, which compete with oxygen to react with nitric oxide thereby inhibiting the generation of nitrite. The IC 50 value of the extract is $51.3 \mu \mathrm{g} / \mathrm{mL}$ while ascorbic acid showed and $\mathrm{IC}_{50}$ value of $77.4 \mu \mathrm{g} / \mathrm{mL}$. Preliminary phytochemical screening of the extract showed the presence of flavonoids and tannins (table 1). Flavonoids have been reported to be associated with antioxidative action in biological systems, acting as scavengers of singlet oxygen and free radicals (Rice-Evans et al., 1997; Jorgensen et al., 1999).

Total antioxidant capacity of the extract, expressed as the number of gram equivalents of ascorbic acid, is shown in figure 2. The extract showed good total antioxidant activity, which was also found to increase in a dose dependent manner. Figure 3 represents the reductive capabilities of the plant extract compared to ascorbic acid. The reducing power of extract of Terminalia chebula Retz. was found remarkable and the reducing power of the extract was observed to rise as the concentration of the extract gradually increased. Earlier authors (Tanaka et al., 1988) have observed a direct correlation between antioxidant activity and reducing power of certain plant extracts. The reducing properties are generally associated with the presence of reductones (Duh et al., 1999), which have been shown to exert antioxidant action by breaking the free radical chain by donating a hydrogen atom (Gordon, 1990).
Table 2: Brine shrimp lethality bioassay of methalnolic extract of $T$. chebula.

\begin{tabular}{lccc}
\hline Sample & LC $_{50}(\mu \mathrm{g} / \mathrm{ml})$ & $\begin{array}{c}\text { Regression } \\
\text { Equation }\end{array}$ & $\mathbf{R}^{2}$ \\
\hline $\begin{array}{l}\text { Vincristine Sulfate } \\
\text { (Positive control) }\end{array}$ & 0.35 & $\mathrm{y}=32.104 \mathrm{x}+64.66$ & 0.9809 \\
T. chebula extract & 97.36 & $\mathrm{y}=46.476 \mathrm{x}+$ & 0.9404 \\
\hline
\end{tabular}

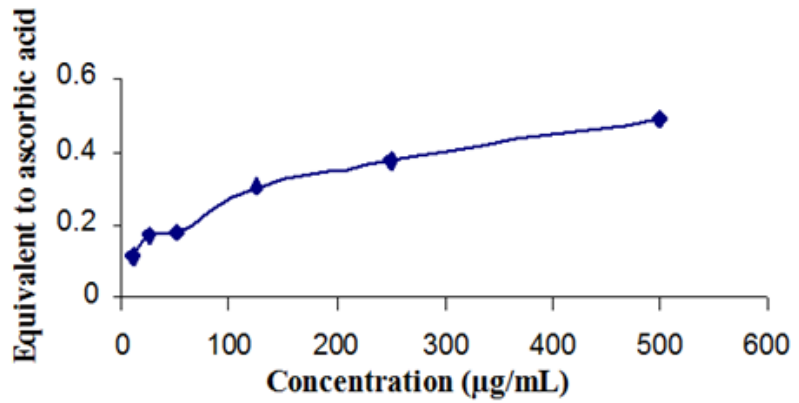

Figure 2: Total antioxidant capacity of Terminalia chebula Retz. vs. ascorbic acid.

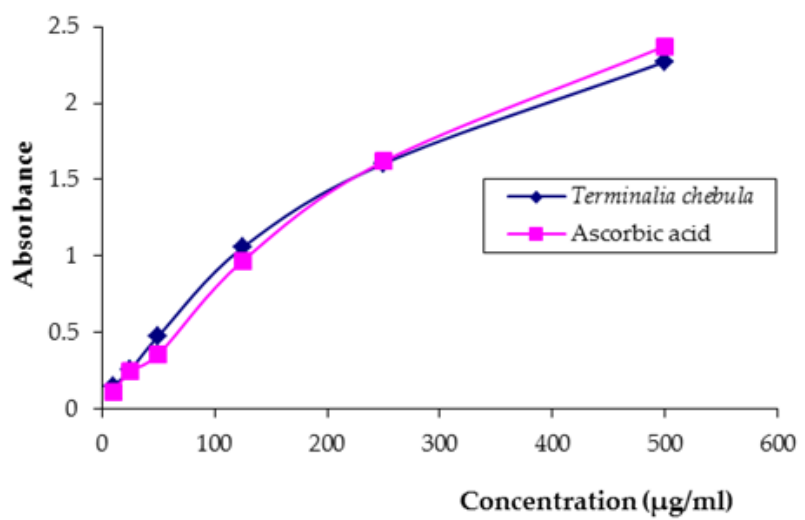

Figure 3: Reducing power of Terminalia chebula vs. ascorbic acid.

The cytotoxic results of the Terminalia chebula Retz. fruit extract, as determined by brine shrimp lethality bioassay is given in Table 2 . The brine shrimp assay is an excellent assay to investigate bioactivity of plant extracts. Terminalia chebula Retz. fruit extract showed moderate cytotoxic activity with an $\mathrm{LC}_{50}$ of $97.36 \mu \mathrm{g} / \mathrm{mL}$. Moderate cytotoxic effects of crude extracts indicate that it can be selected for further cell line assay; because many scientists have shown a direct correlation between cytotoxicity and activity against the brine shrimp nauplii using plant extracts (Martin et al., 1995)

Aforementioned antioxidant results of the Terminalia chebula Retz. fruit extract promoted us to investigate the analgesic potential of the plant using acetic acid induced writhing test in animal models. The results of acetic acid induced writhing test are given in Table 3. The extract significantly and dose dependently inhibited the acetic acid induced writhing in mice $(44.17 \%, \mathrm{p}<0.05$ and, $15.94 \%, \mathrm{p}<0.05$ for 500 and $250 \mathrm{mg} / \mathrm{kg}$ body weight respectively). Acetic acid-induced writhing model 
Table 3: Effect of Terminalia chebula Retz. extract on acetic acid induced writhing in mice.

\begin{tabular}{|c|c|c|c|c|}
\hline Group & Treatment and Dose & Writhing $^{+}$ & No. of writhing & $\%$ of protection \\
\hline Group I & $\begin{array}{l}0.7 \% \text { acetic acid } \\
(10 \mathrm{~mL} / \mathrm{Kg})\end{array}$ & $34.5 \pm 0.866^{*}$ & 100 & 0.00 \\
\hline Group II & $\begin{array}{l}\text { Diclofenac sodium } \\
(25 \mathrm{mg} / \mathrm{kg})\end{array}$ & $11.4 \pm 0.430^{*}$ & 33.04 & 66.96 \\
\hline Group III & $\begin{array}{l}\text { Extract of Terminalia chebula Retz. } \\
\qquad(250 \mathrm{mg} / \mathrm{kg})^{\ddagger}\end{array}$ & $29.0 \pm 1.00^{*}$ & 84.06 & 15.94 \\
\hline Group IV & $\begin{array}{l}\text { Extract of Terminalia chebula Retz. } \\
\qquad(500 \mathrm{mg} / \mathrm{kg})^{\ddagger}\end{array}$ & $19.26 \pm 1.016^{*}$ & 55.83 & 44.17 \\
\hline
\end{tabular}

₹Administered $45 \mathrm{~min}$ before $0.7 \%$ acetic acid administration $(10 \mathrm{ml} / \mathrm{kg})$

${ }^{+}$Counted for $15 \mathrm{~min}$, starting $5 \mathrm{~min}$ after acetic acid administration

" $p<0.05$ vs. control, Dunnett's $t$-test; values are mean \pm S.E.M $(n=3)$

represents pain sensation by triggering localized inflammatory response. Such pain stimulus leads to the release of free arachidonic acid from tissue phospholipids (Ahmed et al., 2006). The acetic acid induced writhing response is a sensitive procedure to evaluate peripherally acting analgesics The response is thought to be mediated by peritoneal mast cells (Ronaldo et al., 2000), acid sensing ion channels (Voilley, 2004) and the prostaglandin pathways (Vogel and Vogel, 1997).

\section{CONCLUSION}

In conclusion, it can be said that the antioxidant, analgesic and cytotoxic activities shown by the Terminalia chebula Retz. fruit extract lend credence in favor of the various uses of Terminalia chebula Retz. in folk medicine. However, extensive pharmacological studies in molecular level are required to understand underlying mechanism of these actions and eventually to isolate active compounds responsible for such activities in $T$. chebula fruit extract.

\section{ACKNOWLEDGEMENT}

The authors are thankful to Chairman, Department of Pharmacy, Stamford University Bangladesh, Dhaka, for providing laboratory facilities to carry out analgesic studies with necessary reagents and animals.

\section{REFERENCES}

Ahmed, F., Hossain, M.H., Rahman, A.A. and Shahid, I.Z. (2006). Antinociceptive and sedative effects of the bark of Cerbera odollam Gaertn. Orien Pharm Exp. Med., Volume 6, Issue 4, Pages 344-348.

Ahmed, F., Selim, M.S.T., Das, A.K. and Choudhuri, M.S.K. (2004). Antiinflammatory and antinociceptive activities of Lippia nodiflora Linn. Pharmazie, Volume 59, Pages 329-333. PMid:15125587

Chatterjee, T.K. (1993). Handbook on Laboratory Mice and Rats. (1st Ed. pp. 157) Department of Pharmaceutical Technology, India, Jadav pur University.

Cheng, H. Y., Lin, T. C., Yu, K. H., Yang, C. M. and Lin, C. C. (2003) Antioxidant and free radical scavenging activities of Terminalia chebula, Biol Pharm Bull, Volume 26, Page 13355. [DOI]

Das, B., (1991). Materia Medica of Ayurveda(8th ed., pp. 8) . New Delhi, B Jain Publisher. PMid:2022768

Duh, P.D., Tu, Y.Y., Yen, G.C. (1999). Antioxidant activity of the aqueous extract of harn jyur (Chrysanthemum morifolium Ramat). Lebensmittel-Wissenschaft and Technologie. Volume 32, Pages 269-277.

Finkel, T., and Holbrook, N.J. (2000). Oxidants, oxidative stress and the biology of aging, Nature, Volume 408, Pages 239-247. [DOI]

Gandhi, N. M. and Nayar, C. K. K. (2005) Radiation protection by Terminalia chebulasome mechanistic aspects, Molecular and Cellular Biochemistry, Volume 277, Page 48. [DOI] PMid:16132713

Ghani, A. (2005) Practical Phytochemistry, (1st Ed. pp. 13-19). Dhaka, Parash publishers of Bangladesh

Gordon, M.H. (1990). The mechanism of antioxidant action in vitro. In Food Antioxidants. Hudson, B.J.F., pp 1-18. Elsevier Applied Science: London, UK.

Halliwell, B. (1996). Oxidative stress, nutrition and health. Experimental strategies for optimization of nutritional antioxidant intake in humans. Free Rad. Res. Volume 25, Pages 1-32. [DOI]

Halliwell, B., and Gutteridge, J.M.C. (1999). Free Radicals in Biology and Medicine, (3rd ed.), Oxford, Oxford University Press

Hushum, S.M., Harkonen, P. and Pihlaja K. (2002) Inhibition of cancer cell grow th by crude extract and phenolics of Terminalia chebula fruit, Journal of Ethnopharmacology, Volume 81, Page 336.
Jayaprakash, G.K., and Rao, L.J. (2000). Phenolic constituents from lichen Parmontrema stuppeum. Food Control. Volume 56, Pages 1018-1022

Jeong, A. H. N., Kim, C. Y., Lee, J. S., Kim, T. G., Kim, S. H., Lee, C. K., Lee, B., Shim, C. G., Hoon, H.and Kim, J. (2002) Inhibitors of HIV-1 integrase by galloyl glucose from Terminalia chebulaand flovonol glycoside gallates from Euphorbia pekinensis, Planta Medica, Volume 68, Page 459.

Jorgensen, L.V., Madsen, H.L., Thomsen, M.K., Dragsted, L.O.and Skibsted, L.H. (1999). Regulation of phenolic antioxidants from phenoxyl radicals: An ESR and electrochemical study of antioxidant hierarchy. Free Rad. Res. Volume 30, Pages 207-220. [DOI]

Kumaran, A. and Karunakaran, J. (2006). Nitric oxide radical scavenging active components from Phyllanthus amblica L. Plant Food Human Nutri. Volume 61, Pages 1-5. [DOI] PMid:16688481

Liu, X., Cui, C., Zhao, M., Wang, J., Luo, W., Yang, B., Jiang, Y. (2008). Identification of phenolics in the fruit of emblica (Phyllanthus amblica) and their antioxidant activities. Food Chem. Volume 109, Pages 909-915. [DOI]

Martin, C., Saenz, M.T. and Ayuso, M.J. (1995). Cytotoxic activity of Retama spaero carpa. Fitoterapia. Volume 66, Pages 495-498.

McLughilin, J.L., (1991). Bench top bioassays for the discovery of bioactive compounds in higher plants. Brenesia. Volume 34: Pages 1-14.

Meyer, B.N., Ferringm, N.R., Puam, J.E., Lacobsen, L.B., Nichols, D.E. and MeLaughlin, J.L. (1982). Brine shrimp: a convenient general bioassay for active constituents. Planta Med. Volume 45, Pages 31-32. [DOI]

Miglani B. D., Sen P. and Sanyal P. K. (1971) Purgative zaction of an oil obtained from Terminalia chebula, Indian J Med Res, Volume 52, Page 283.

Oyaizu M (1986). Studies on product of browning reaction prepared from glucosamine. Japn. J. Nutri. Volume 44, Pages 307-315. [DOI]

Persoone G (1980). Proceeding of the International Symposium on brine shrimp, Artemia salina, Vol. 1-3, Universa Press, Witteren, Belgium.

Prieto, P., Pineda, M. and Aguilar, M. (1999). Spectrophotometric quantification of antioxidant capacity through the formation of a phosphomolybdenum complex: Specific application to the determination of vitamin E. Anal Biochem. Volume 269, Pages 337-341. [DOI] PMid:10222007

Rice-Evans C, Sampson J, Bramley PM and Hollow ay DE (1997) Why dowe expect carotenoids to be antioxidants in vivo. Free Rad Res. Volume 26, Pages 381-398. [DOI] PMid:9167943

Ronaldo AR, Mariana LV, Sara MT, Adriana BPP, Steve P, Ferreira SH and Fernando QC (2000). Involvement of resident macrophages and mast cells in the writhing nociceptive response induced by zymosan and acetic acid in mice. Eur J Pharmacol. Volume 387, Pages 111-118. [DOI]

Sato, Y., Oketani, H., Singyouchi, K., Ohtsubo, T., Kihara, M., Shibata, H. and Higuti, P. (1997) Extraction and purification of effective antimicrobial constituents of Terminalia chebula Retz. Against methicillin- resistant Staphylococcus aureus, Biol Pharm Bull, Volume20, Page 404. [DOI]

Sreejayan N, Rao MNA (1997). Nitric oxide scavenging by curcuminoids. J Pharm Pharmacol. Volume 49, Pages 105-107. [DOI] PMid:9120760

Srikanthmurthy, K. R. (2000) Bhavaprakasha of Bhavamishr (pp.160). Krishnanda AcademyVaranasi

Sumantran, V.N., Kulkarni, A., Chandwaskar, R., Harsulkar, A., Patwardhan, B. Chopra, A. and Wagh, U.V. (2007). Chondroprotective potential of fruit extracts of Phyllanthus emblica in osteoarthritis. eCAM:1-7, [DOI]

Tanaka, M., Kuie, C.W., Nagashima, Y., Taguchi, T. (1988). Applications of antioxidative maillard reaction products from histidine and glucose to sardine products. Nippon Suisan Gakkaishi. Volume 54, Pages 1409-1414. [DOI]

Thakur, C. P., Thakur, B., Singh S and Sinha, S. K. (1988) The Ayurvedic Medicines Haritaki, Amla and Bahira reduced cholesterol induced atherosclerosis in rabbits, Int J. Cardiol, Volume 21, Page 175. [DOI]

Vogel, H.G. and Vogel, W.H. (1997). Pharmacological Assays. In: Drug Discovery and Evaluation. Chapter H, pp. 368-370. Springer Verlag, Germany. [DOI]

Voilley, N. (2004). Acid-Sensing Ion Channels (ASICs): New Targets for the Analgesic effects of Non-Steroid Anti-Inflammatory Drugs (NSAIDs). Current Drug Targets- Inflammation \& Allergy. Volume 3, Pages 71-79. [DOI] PMid:15032643 